\title{
Book review of Fault Lines by Raghuram G. Rajan
}

\section{Emilia Garcia-Appendini}

\begin{abstract}
Most people believe that the recent financial crisis had its roots in a boom in housing lending in the United States. After the dot-com bubble, the argument goes, the Federal Reserve Bank lowered the interest rates to stimulate corporate investment and recover from the downturn. As a side effect of low interest rates, mortgages became cheaper and Americans became attracted to the housing market. Credit for housing was provided by the sophisticated financial system of the United States, which allowed investors to purchase packages of mortgages from diversified geographical locations, and from individuals with different probabilities of default, according to their desired level of risk. As it turned out, these products caught the attention of investors from all over the world, who were attracted by their profitable returns and the implicit guarantees provided by the U.S. government to the issuing agencies and financial intermediaries. Therefore, housing credit was plentiful and, as a consequence, house prices in the United States rose. This in turn allowed mortgage borrowers to refinance their debts and avoid default. The party came to an end when interest rates increased and house prices fell, triggering a series of defaults in mortgages and driving values of the financial products near to zero, resulting in consequences with which we all are too familiar.

In Fault Lines, Raghuram Rajan argues that this widely accepted explanation for the crisis fails to acknowledge that there are deeper economical, political, and social frictions outside the financial system, both domestic to the United States and international, which played a central role in the evolution of events described above. These frictions are comparable to geological fault lines or fissures in the Earth's surface, where different tectonic plates come into contact, building up enormous stresses around them.
\end{abstract}

E. Garcia-Appendini $(\varangle)$

University of St. Gallen, St. Gallen, Switzerland

e-mail: emilia.garcia@unisg.ch 
The first fault line stems from U.S. domestic political and social pressures, which fed on a growing inequality. Between 1975 and 2005, the difference between the wages in 90th and the 10th percentiles of the distribution increased substantially, leaving the working class severely marginalized. The author argues that the increase in inequality was driven partly by the U.S. educational system, which is at the bottom of the ladder internationally, coupled with the increasing cost of a college education. These factors led to stagnation in the supply of a well-educated labor force right at the time when the demand for such labor was increasing, driving the wages of the lucky (and often already well-heeled) few upward. At the same time, the expansion in global trade and immigration intensified competition for blue-collar workers, keeping the wages of the working class stagnant. But rather than addressing these structural imbalances, for example, by improving the U.S. educational system, vote-seeking politicians chose the solution that delivered visible results in the shortest term possible: boosting consumption by the marginalized by supporting social programs that increased their access to housing credit.

Another set of fault lines is related to international trade imbalances. Countries such as Japan and Germany and, recently, some Asian countries (including China) have been able to grow by relying excessively on exports to foreign countries and by protecting their inefficient domestic-oriented production sector from global competition. Excess consumption of goods produced in other countries does not necessarily drive prices up in the local market, and thus central banks do not see the need to increase the interest rate in order to curb consumers' desire to take on more debt so as to keep consuming. At the same time, the inefficient domestic sectors of exporter countries are unable to create enough internal demand to reduce their dependence on foreign countries for growth, which increases the trade imbalances. This spiral continues until the levels of debt of consumer countries such as the United States, the United Kingdom, and Spain, become unsustainable, and crisis hits everywhere.

The third set of fault lines emerges when these trade imbalances are financed by individuals in different financial systems. For example, the East Asian crises of the 1990s occurred because foreign investors, not used to the lack of transparency in these bank-oriented economies, protected themselves against the risk of default by offering short-term, foreign-currency-denominated funds that could easily be withdrawn and were not subject to devaluation, and lent the funds through local banks that had implicit government guarantees. Similarly, in the recent financial crisis, foreign investors naively overrelied on the accuracy of prices in the arm's-length financial system of the United States, and offered their funds through institutions that had implicit U.S. government guarantees.

The fault lines all came together in the U.S. financial sector because the limited unemployment safety net in this economy, coupled with the jobless recoveries of the 1980s and early 1990s, put a lot of pressure on the Fed to intervene and create as much fiscal and monetary stimulus as possible to create the necessary jobs. By doing so, the incentives to take greater risks in the financial sector increased.

Rajan warns that these fault lines did not disappear after the recent financial crisis, and that they need to be tackled to avoid another, possibly deeper crisis, or even destructive warfare. The challenge facing us, however, is that, ultimately, these fault lines exist because everybody is acting according to what is best for them individually. 
Nevertheless, in the last chapters, the author discusses possible constructive reforms, sometimes painful in the short term, that could be implemented to reach long-term solutions. The author also discusses how public pressure could be created to achieve the implementation of these reforms.

Fault Lines is a very well written and cogent book that provides a global perspective on the causes of the crisis, the dangers if the root causes of it are not addressed, possible solutions, and ideas for implementing them. The book explains many economic concepts and developments in simple language that should be accessible to the wider public. More knowledgeable readers who are familiar with these issues will enjoy the book's descriptions of historical events and references to entertaining academic experiments and articles that support the author's arguments. A strict empirical academic might complain about the lack of empirical evidence for some of the author's boldest causal claims, but such gaps could also be viewed as an excellent source of inspiration for young researchers looking for research ideas. In sum, this book is a must read for analysts, academics, politicians, economists, and the like.

\section{Author Biography}

Prof. Emilia Garcia-Appendini is an assistant professor of Finance at St Gallen University, Switzerland. She holds a Ph.D. in Economics and Finance from Universitat Pompeu Fabra, Spain. Her research focuses on corporate finance, banking, and private equity, and has been published in the Journal of Financial Economics and the Journal of Financial Intermediation. 